M.I. Baranov

\title{
AN ANTHOLOGY OF THE DISTINGUISHED ACHIEVEMENTS IN SCIENCE AND TECHNIQUE. PART 45: TRADITIONAL POWER ENGINEERING. HYDRAULIC POWER PLANTS: STATE AND PROSPECTS OF THEIR DEVELOPMENT
}

\begin{abstract}
Purpose. Preparation of brief scientific and technical review about the state, achievements, problems and prospects of development of world hydraulic power engineering. Methodology. Known scientific methods of collection, analysis and analytical treatment of the opened scientific and technical information, present in scientific monographs, journals and internet sources, high meaningfulness in area of hydraulic power engineering. Results. A brief analytical scientific and technical review is resulted about the present state, achievements, problem tasks and prospects of development of hydraulic power engineering in the industrially developed countries of the world. Considerable progress is marked in development and creation of technical base of modern hydraulic power engineering including powerful hydraulic turbines and hydraulic electric generators. Existent classification of the hydraulic power plants (HPPs) is resulted. Basic types and constructions of powerful hydraulic turbines, in-use on modern HPPs are presented. Basic kinds and technical descriptions of powerful hydraulic electric generators used at modern HPPs are indicated. Information is resulted about the largest in the world ordinary HPPs and hydraulic heat-sink HPPs. Hydraulic power engineering of Ukraine is considered and descriptions of basic domestic HPPs are described. Advantages and failings of HPPs are marked in comparison with the thermal and nuclear power plants. Information is presented about absolute volumes of electric power produced by HPPs in a number of the industrial developed countries of the world. Quantitative indexes are resulted for today in the world of reserve of hydraulic power resources on the continents of our planet. A conclusion is done that this reserve of hydraulic power resources is mainly concentrated in the countries of Asia. It is indicated that hydraulic power engineering of the world produces presently up to $21 \%$ of electric energy in annual world in the electrical energy balance. Some problem tasks of world hydraulic power engineering are indicated. Certain prospects are outlined in development of hydraulic power in the world and in Ukraine. Originality. Systematization is executed as short structured of scientific and technical review of the scientific and technical materials touching functioning of such important sector of world economy as hydraulic power engineering known from the open sources in informative space. Material is expounded from positions of scientist-electrophysics in an accessible for a wide reader new informatively-rich content form. Practical value. Popularization and deepening for students, engineers and technical specialists and researchers of front-rank scientific and technical knowledge in area of modern hydraulic power engineering extending their scientific range of interests and promoting further development of scientific and technical progress in society. References 21 , figures 13.
\end{abstract}

Key words: hydropower engineering, hydraulic power plants, hydraulic turbines, hydraulic electric generators, characteristics of hydraulic power plants, problems and prospects of development of world hydropower engineering.

Приведен краткий научно-технический обзор о современном состоянии и перспективах развития мировой гидроэнергетики. Рассмотрены основные схемы построения и виды гидравлических электрических станций (ГЭС). Указаны преимущества и недостатки ГЭС перед другими видами электрических станций, генерирующих электричество. Приведены основные технические характеристики крупнейших ГЭС мира и Украины. Отмечена ваэнная роль гидроэнергетики в объемах годовой выработки электроэнергии в ряде стран мира. Обозначены проблемные задачи в области гидроэнергетики мира и Украины. Библ. 21, рис. 13.

Ключевые слова: гидроэнергетика, гидроэлектростанции, гидротурбины, электрогидрогенераторы, характеристики гидроэлектростанций, проблемы и перспективы развития мировой гидроэнергетики.

Introduction. By and large, nature on the planet Earth has created a wonderful substance - water, a molecule of which, as we all know, consists of two atoms of hydrogen and one oxygen atom. This substance in the usual molecular form (light water, consisting of the atoms of the isotope of hydrogen ${ }_{1}^{1} \mathrm{H}$ - protium and the isotope of oxygen $\left.{ }_{8}^{16} \mathrm{O}[1]\right)$ is the basis of the life activity of everything on our planet (possibly not only on the planet Earth!). It is on it that all the basic physicochemical processes of metabolism in the plant and animal world are based. As civilizations evolved, people learned how to use not only the intramolecular energy of water in their life activity, but also its potential energy to bring the wooden aggregates with circular millstones to circular rotation in order to obtain from the grain of agricultural crops flour and then bread baking, and later round metal rotor of an electric generator which generates electricity in the windings of its stator. To increase the potential energy reserves in the water on the way of its movement and its pressure, it was necessary to build reinforced concrete dams (Fig. 1) and correspondingly huge reservoirs with a large difference (in tens and hundreds of meters) of water levels before and after the dams. In this connection, expensive and reliable hydraulic engineering facilities were required ensuring the operation of each powerful hydraulic power station (HPP). The possibility of serious accidents with the breakthrough of the dam at such facilities by specialists in hydropower engineering should be minimized. Otherwise, the material damage and the inevitable death of people can take huge scales. One of the evidence of this is the data on one of the biggest accidents in the history of the world hydraulic power engineering during the breakthrough of the dam of the Bainjiao reservoir on the Zhuhe River (Henan Province, China, 1975) which resulted in the death of approximately 171,000 people and the number of casualties in the number of 11 million Chinese citizens [2]. This catastrophe at the Chinese HPP for the damage caused to society is comparable to the shock of the entire civilized 
world by the atomic bombardment by the USA on August 6, 1945 of the Japanese city of Hiroshima which in one instant was actually completely wiped out with people and their houses from the «face» of our planet [3]. What is the role of HPPs now in the balance of the generation of electricity in the world and in Ukraine? What are the prospects for the development of hydraulic power engineering? We try to answer these questions below.

The goal of the paper is compilation of a brief scientific and technical review on the current state and prospects of development in the world of hydraulic power engineering.

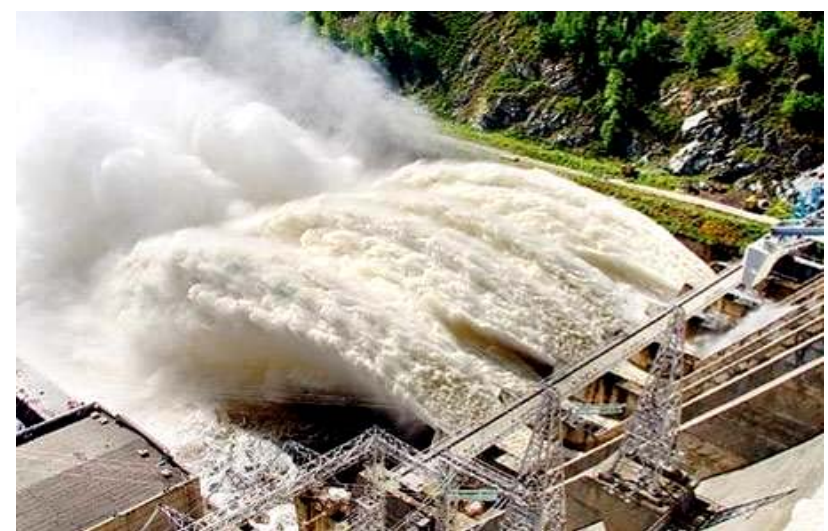

Fig. 1. Impressive and mesmerizing our imagination the power of river water discharged through open water lines in a reinforced concrete dam from an artificially created reservoir of modern HPP [2]

1. Physical basis of hydraulic power engineering. To begin with, we point out that hydraulic power engineering is based on HPPs - power plants which use the potential and kinetic energy of water masses as a stable source of energy [2]. Typically, HPPs are built on high-water rivers building the necessary dams and reservoirs on them. Fig. 2 shows a schematic diagram of the construction of HPPs containing the following main devices [2, 4]: massive reinforced concrete dam with pressure water conduits; a machine hall with hydroelectric units installed in it containing hydraulic turbines and electric generators. A powerful flow of water from the reservoir along the water conduits with the help of blades is directed to the impeller blades of the hydraulic turbine of design shown in Fig. 3. The rotational rotation of the blades of the impeller of this turbine causes corresponding rotation of its vertically mounted massive metal shaft on which the rotor of a hydraulic electric generator rotating normally in the horizontal plane is installed providing a rotating and sinusoidal time-varying high magnetic field with magnetic flux density of about $1 \mathrm{~T}$ in the air gap between the rotor and stator of the hydraulic electric generator (see Fig. 3).

Due to the fundamental phenomenon of electromagnetic induction [1] in the stator windings of the hydraulic electric generator spatially and phasically spaced apart from each other by $120^{\circ}$, a three-phase electromotive force and a correspondingly high electrical potential are generated. The presence of this potential ensures the flow of a three-phase AC with frequency of $50 \mathrm{~Hz}$ in the primary winding of the transformer connected on one side to the output terminals of the hydraulic electric generator and, on the other hand, to a high-voltage transmission line supplying electricity to the corresponding consumers. The electrical power of the HPP is determined mainly by the head and the flow of water entering the blades of its hydraulic turbines. To a lesser extent, it depends on the efficiency of hydraulic turbines (up to $80 \%$ ) and hydraulic electric generators (up to $98 \%$ ) $[2,4]$. Due to the fact that the level of water in reservoirs varies during a year according to natural laws, hydraulic power specialists traditionally use the concept of cyclic power of HPP (for example, during the year, month, week and day) $[2,4]$.

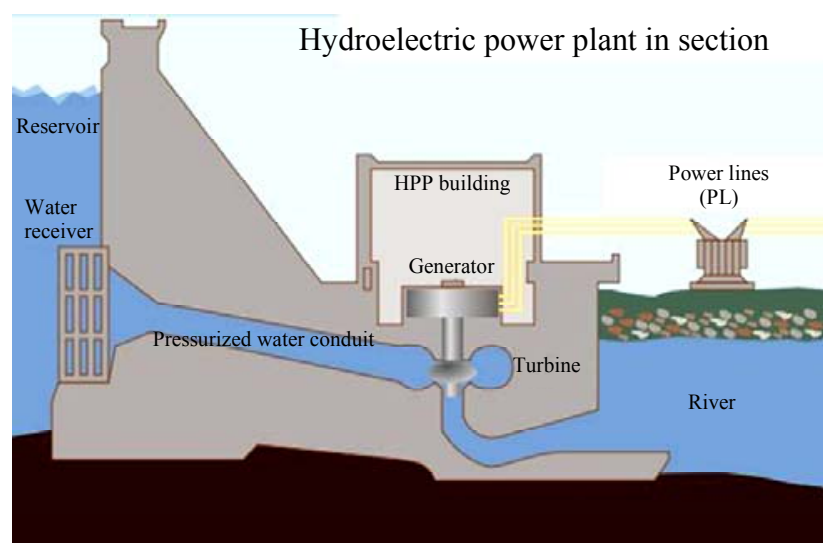

Fig. 2. Schematic diagram of the HPP construction [2]

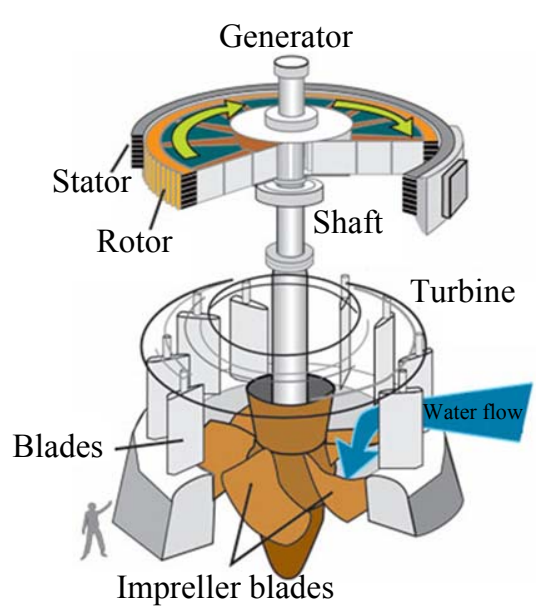

Fig. 3. Block-constructive diagram explaining the principle of operation of a hydraulic turbine and the physical mechanism of generating electrical energy at a modern HPP [2]

1.1. The main classification of HPPs. Depending on the principle of use of renewable natural resources and the way of concentration of water masses, it is possible to single out HPPs of the following type [2, 4]:

- near dams HPPs (reinforced concrete dams, completely blocking the river, raise the level of its water to the required mark, water to the hydraulic turbines comes directly from the river bed);

- dam HPPs (built at higher headings of river water when reinforced concrete dams completely block the river, the building of the HPP is located behind the reinforced concrete dam in its lower part, and water flows to the hydraulic turbines through special pressure tunnels or conduits); 
- derivational HPPs (built where the slope of a mountain river is large, the necessary concentration of river water for the efficient operation of its hydraulic turbines is created by non-pressure or pressure derivation (the term «derivation» comes from the Latin word «derivatio» - «diversion» [5]); the type of derivation applied to the HPP (the type of diversion of water from the main river bed) depends on the nature of the slope of the water conduit that supplies river water to the turbine blades);

- pumped storage HPPs (they are built to smooth out peak electrical loads of electricity consumers, water is pumped from the river to a special reinforced concrete upper pool beforehand, and at the appropriate time it is transferred to hydraulic turbines via pressure pipelines from this pool);

- tidal HPPs (usually built in the rocky places of the canyon type with a high level of sea tide reaching up to 19 $\mathrm{m}$ in the world [6], a reinforced concrete dam with reversible hydraulic turbines installed at its base in special round canals creates a huge coastal basin of the sea or oceanic water during tide, the energy of this moving water is used by hydraulic turbines both during high tide and low tide);

- wave HPPs (built in the coastal sea area with high waves, this type of HPP transforms the potential energy of sea water pumped by the waves themselves into special containers on the sea surface into electricity).

Depending on the level of water pressure applied to the hydraulic turbines, HPPs are divided into [2, 4]:

- high-pressure HPPs (the level of water pressure in the water conduits to its hydraulic turbines is more than $60 \mathrm{~m})$;

- medium-pressure HPPs (the level of water pressure in the water conduits to its hydraulic turbines from 25 to $60 \mathrm{~m})$;

- low-pressure HPPs (the level of water pressure in the water conduits to its hydraulic turbines from 3 to $25 \mathrm{~m}$ ).

Depending on the level of electric power generated by hydraulic electric generators, HPPs are divided into the following main types [2, 4]:

- high-power HPPs (their electric power is more than $25 \mathrm{MW}$;

- medium-power HPPs (their electric power is from 5 to $25 \mathrm{MW})$;

- low-power HPPs (the electric power produced by them is no more than $5 \mathrm{MW}$ ).

1.2. Classification and basic designs of hydraulic turbines. At the HPPs, depending on the level of the water pressure, different designs of hydraulic turbines are used. There are the following types of hydraulic turbines $[2,4]$ :

- rotary-blade hydraulic turbines (Fig. 4);

- radial-axial hydraulic turbines (Fig. 5);

- bucket hydraulic turbines (Fig. 6).

Fig. 4 shows a general view of a powerful rotaryblade hydraulic turbine for a modern HPP [7]. This type of turbine (Kaplan reactive turbine [7]) is installed at medium-pressure and low-pressure HPPs. Blades of complex shape in this hydraulic turbine can be rotated simultaneously around their horizontal axis, Due to this and the change in the position of its blades (see Fig. 3), the power produced by the turbine is regulated [7].

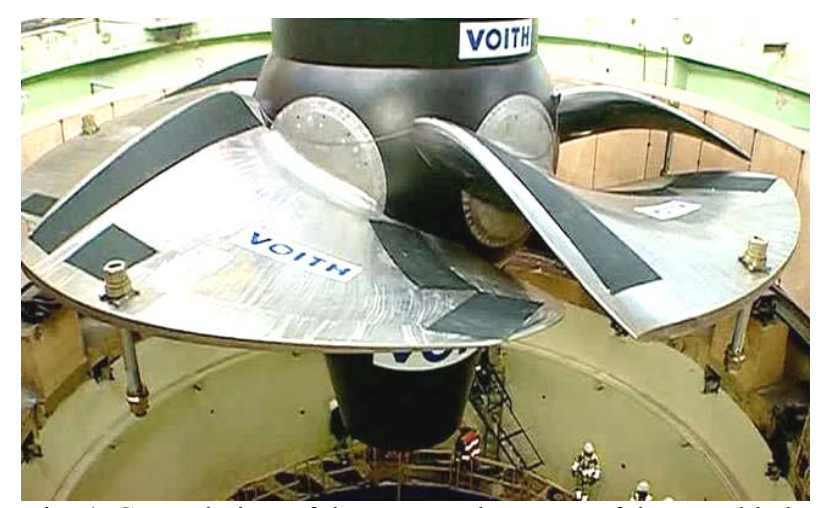

Fig. 4. General view of the new modern powerful rotary-blade hydraulic turbine at the time of its installation at the HPP [7]

The flow of water in the rotary-blade hydraulic turbine moves along its axis. The longitudinal axis of this turbine can be located both vertically and horizontally. With the vertical arrangement of the axis, the flow of water before entering the working chamber of the turbine is twisted in a spiral chamber, and then rectified with the help of a fairing. This is necessary for a uniform supply of water to the blades of such a turbine and, accordingly, to reduce its wear.

Fig. 5 represents a general view of the impeller of a powerful radial-axial hydraulic turbine designed for installation at the machine room of the largest in Russia Sayano-Shushenskaya HPP of dam type with installed power up to $6400 \mathrm{MW}[2,4]$.

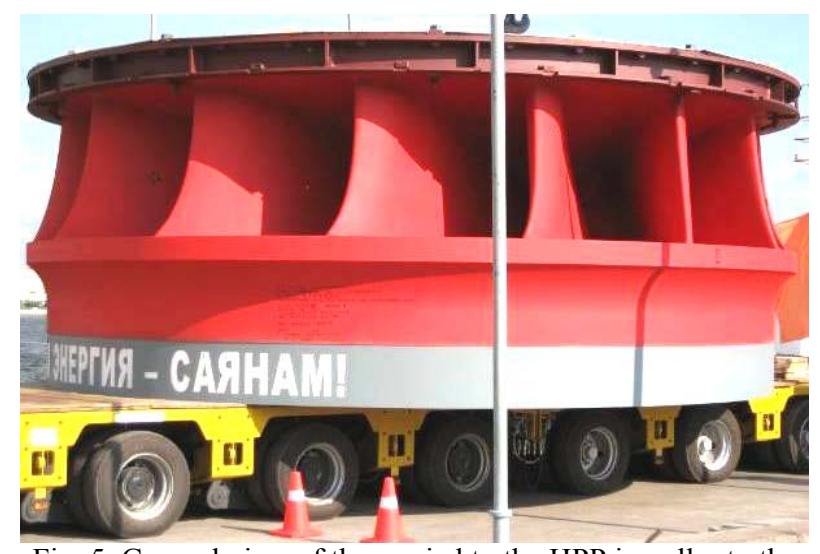

Fig. 5. General view of the carried to the HPP impeller to the HPP of a modern powerful radial-axial hydraulic turbine [7]

Radial-axial hydraulic turbines (the Francis reactive turbine [7]) are used in high-pressure HPPs. The water flow in this turbine first moves radially (from the periphery to its center), and then in the axial vertical direction to the outlet from the turbine. This type of hydraulic turbine is used at HPPs with water pressure generated by their dams up to $600 \mathrm{~m}$ and their powers up to $640 \mathrm{MW}$ [7]. Of all the known types of hydraulic turbines, radial-axial hydraulic turbines have the highest efficiency. Their disadvantage is a less regular working characteristic than that of rotary-blade hydraulic turbines $[4,7]$.

Fig. 6 shows a general view of the bucket hydraulic turbine installed on high-pressure HPPs. 


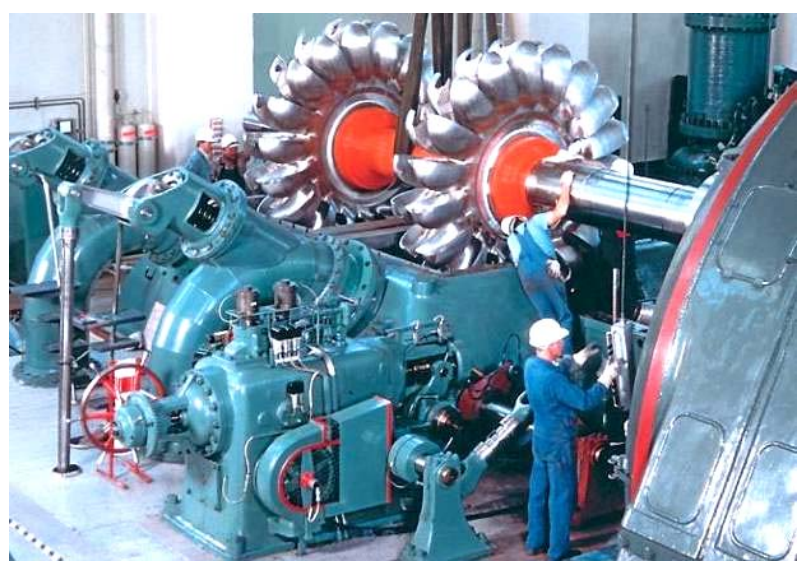

Fig. 6. General view of a bucket hydraulic turbine operating at a high-pressure HPP at the time of its maintenance

(to the right of the two bucket hydraulic turbines along the longitudinal axis of the massive steel shaft the body of the hydraulic generator is visible) [7]

Constructively bucket hydraulic turbines (Pelton turbine [7]) are very different from rotary-blade and radial-axial hydro turbines. They, like steam turbines [8], are installed on a horizontal massive steel shaft common with the hydraulic generator. In this type of hydraulic turbine, water is supplied by a large pressure through nozzles (almost like water vapor) along a tangent to the circle passing through the middle of each of its highstrength buckets of special shape placed on both sides of its wheel (see Fig. 6). The jets of water leaving the nozzles at high speed lead to a circular rotation of this hydraulic turbine and the steel shaft of the hydraulic electric generator paired with it. In the bucket hydraulic turbine, the use of the kinetic energy of high-speed jets of river water caused by the dam created by the reservoir with the pressure of water is carried out at atmospheric pressure. Bucket hydraulic turbines (Fig. 7) are used for water pressures of $300 \mathrm{~m}$ and more $[7,9]$. The power of the bucket hydraulic turbines can reach 200-250 MW with water flow in them up to $100 \mathrm{~m}^{3} / \mathrm{s}$. With a pressure of water up to $700 \mathrm{~m}$ (with its excess pressure up to $70 \mathrm{~atm}$ ), bucket hydraulic turbines compete on HPPs with radialaxial hydraulic turbines. With higher water pressures, their use at HPPs remains uncontested today [7]. The disadvantage of bucket hydraulic turbines is their inefficiency with small pressures and high demands on the river water supplied to them (it should not contain sand and other inclusions that lead to severe wear of the working surfaces of the steel elements of the turbine).

1.3. The main types and characteristics of hydraulic electric generators of HPPs. The hydraulic electric generators used at HPPs with rotary-blade and radial-axial hydraulic turbines are usually a synchronous salient-pole electric machine of vertical design (Fig. 8) driven into rotation from a turbine of a particular design. Note that there are separate designs of low-power hydraulic electric generators of horizontal design including capsular reversible hydraulic electric generators used at tidal HPPs [4, 6]. The hydraulic electric generators with these turbines have a small frequency of circular rotation (up to $500 \mathrm{rpm}$ ) and a relatively large outer diameter (up to $20 \mathrm{~m}$ ) [11]. It is these characteristics that determine the vertical performance of hydraulic

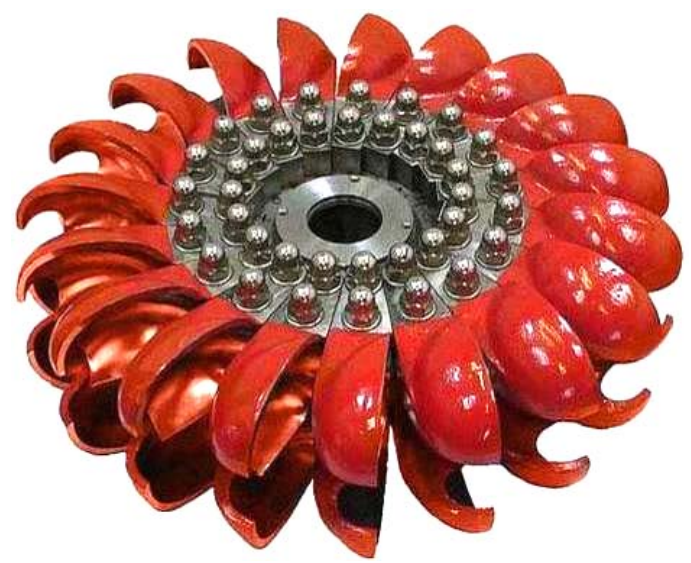

Fig. 7. Enlarged view of a new impeller of a modern powerful bucket hydraulic turbine before its installation in the machine room of a high-pressure HPP [10]

electric generators at all HPPs with rotary-blade and radial-axial hydraulic turbines. With their horizontal design, the rigidity and mechanical strength of elements of similar electrical devices becomes technically not feasible [11]. Hydraulic electric generators of horizontal design are used at HPPs with bucket hydraulic turbines, the rotor speed of which, depending on their pole number (in the presence of 4 or 2 magnetic poles), can reach 1500 or $3000 \mathrm{rpm}$ [8]. Pumped storage HPPs use reversible hydraulic electric generators that operate both in the mode of electricity generation and its consumption during the pumping of river water into the upper basin of such a HPP. They are different from ordinary hydraulic electric generators by a special design of the thrust bearing, allowing their rotor to rotate in both directions [11]. Hydraulic electric generators are designed specifically for the rotational speed and power of hydraulic turbines used at HPPs (for example, for single radial-axial hydro turbines of $640 \mathrm{MW}[4,7])$.

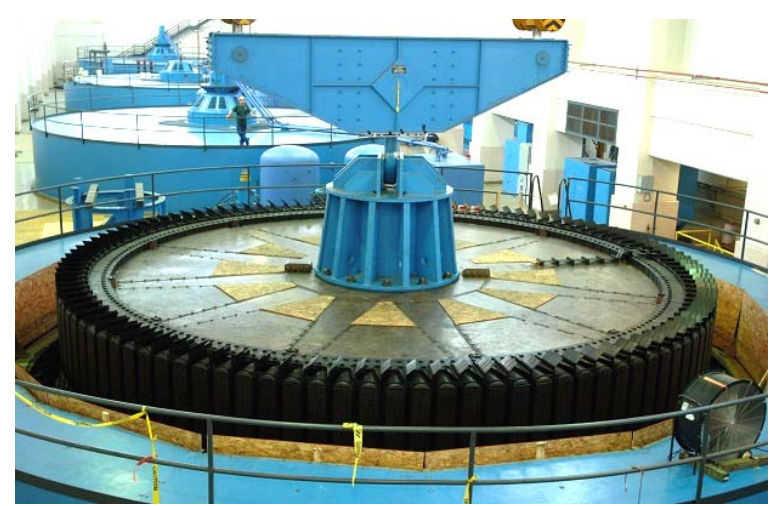

Fig. 8. General view of the machine hall of a powerful HPP at the moment of lifting the rotor of one of its large-sized hudraulic electric generators of vertical design [4]

Hydraulic electric generators of HPPs for large unit power (see Fig. 8) are usually installed vertically on the bearings with corresponding guide bearings [11]. They are performed as three-phase ones for frequency of $50 \mathrm{~Hz}$. They use high-efficiency air cooling systems with air-towater heat exchangers.

2. The largest HPPs in the world. Among the world's largest hydroelectric power stations are the following [2]: 
- HPP «Three Gorges» with installed power of 22,400 MW (PRC, Yangtze River, Sandoupin, average annual power generation is 98 billion $\mathrm{kWh}$ );

- HPP «Itaipu» with installed power of 14,000 MW (Brazil/Paraguay, Parana, Foz do Iguaçu, average annual power generation at this inter-border station is 92 billion $\mathrm{kWh}$;

- HPP «Silodu» with installed power of 13,900 MW (PRC, Yangtze river, average annual power generation is 64.8 billion $\mathrm{kWh}$ );

- HPP «Guri» with installed power of 10,300 MW (Venezuela, Caroni river, average annual power generation is 40 billion $\mathrm{kWh}$ );

- HPP «Tukurui» with installed power of 8,300 MW (Brazil, Tokantins River, average annual power generation is 21 billion $\mathrm{kWh}$ );

- HPP «Sayano-Shushenskaya» with installed power of 6,400 MW (Russia, the Yenisei River, Sayanogorsk, average annual power generation is 23.5 billion $\mathrm{kWh}$ );

- HPP «Krasnoyarskaya» with installed power of 6,000 MW (Russia, the Yenisei River, Divnogorsk, average annual power generation is 20.4 billion $\mathrm{kWh}$ );

- HPP «Churchill Falls» with installed power of 5,400 MW (Canada, Churchill River, average annual power generation is 35 billion $\mathrm{kWh}$ );

- HPP «Bratskaya» with installed power of $4520 \mathrm{MW}$ (Russia, Angara River, Bratsk, average annual power generation is 22.6 billion $\mathrm{kWh}$ ).

Fig. 9 shows a general view of the largest in the RF Sayano-Shushenskaya HPP with capacity of $6.4 \mathrm{GW}$, built on a large Siberian river Yenisei and is a typical dam type (on its photo, descending from a dam of $242 \mathrm{~m}$ high down to the machine hall with 10 radial-axial hydraulic turbines of $640 \mathrm{MW}$ each 10 water lines are visible) [4, 7].

The sad statistics in the field of world hydraulic power engineering on our «eyes» also touched upon this modern powerful HPP. On August 17, 2009 at the Sayano-Shushenskaya HPP there was a major accident with large disruptions in the machine hall, which resulted in the death of 75 workers in the power plant [2, 4]. It took about two years to restore it.

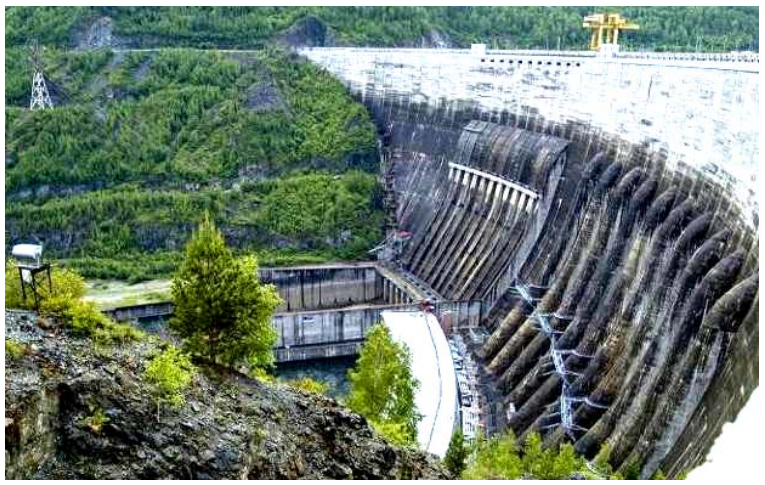

Fig. 9. General view of the largest in Russia SayanoShushenskaya HPP of dam type with power of $6400 \mathrm{MW}$ (the Yenisei River) [4]

3. The largest pumped storage power plants in the world. In brief, we will focus on hydroelectric power plants whose main purpose is to «remove» peak electrical loads of consumers in their countries' electric power systems (for example, in the evening, when people return home after work and switch on devices that use electricity from the grid). Eliminate the resulting shortage of electricity by increasing the volume of its production at thermal power plants [8], nuclear power plants [12] and conventional hydraulic electric power plants is technically impossible. These power plants for the stability of their power units and, accordingly, the country's energy system as a whole should operate in their «cruising» mode excluding any actions to transfer them to a maneuverable work schedule in a short time. For these purposes, additional energy capacities and resources are needed. One of such resources is pumped storage power plants using their pre-filled upper basins (reservoirs) during the period of peak loads of consumers to generate additional power flows in the power system with the help of hydraulic turbines and hydraulic electric generators at these HPPs, increasing the reliability of its operation [13]. Fig. 10 shows the general view of the reservoir of a pumped storage power plant (near the Missouri River, 80 $\mathrm{km}$ from Mississippi, USA), with power of 5.55 billion liters [15]. During the period of peak loads this power plant develops power up to $440 \mathrm{MW}$.

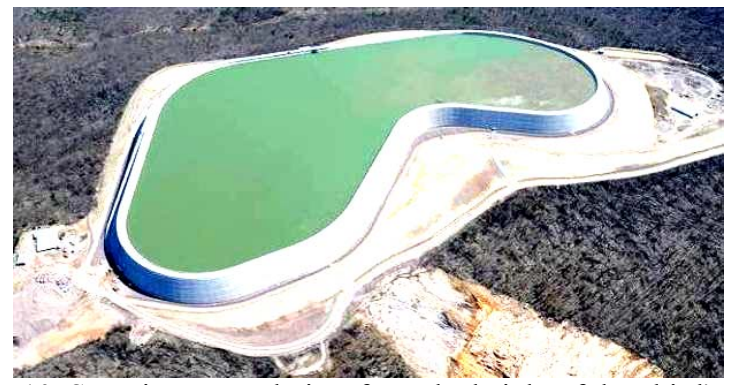

Fig. 10. Stunning general view from the height of the «bird's eye view» of the huge reinforced concrete reservoir at the top of the remote from the cities of the mountain range of the modern

pumped storage power plant «Taum Sauk» (USA) [13]

One of the world's largest pumped storage hydroelectric power plants should be the created since 1983 in Ukraine near the river Dniester (Chernivtsi region) Dniester hydraulic electric power plant with generating power of about $2268 \mathrm{MW}$ (power in the pumping mode is approximately $2847 \mathrm{MW}$ ) [14].

4. Hydropower engineering of Ukraine. Domestic hydropower actually began with the construction in the period 1927-1932 on the river Dnieper (Zaporozhye) of the largest at that time in Europe the Dneprovskaya HPP with installed power of $1548 \mathrm{MW}$ [14]. Fig. 11 shows the general view of the hydraulic turbine hall of this HPP.

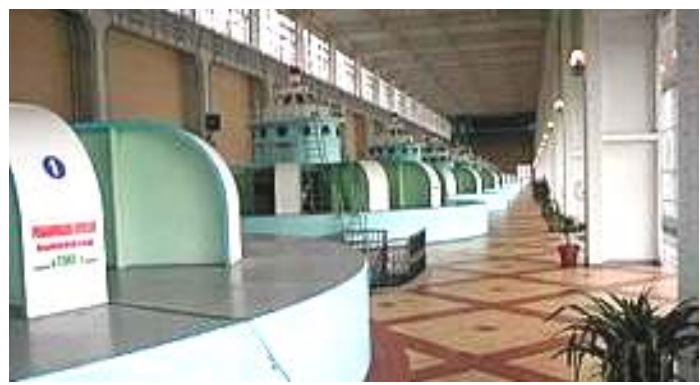

Fig. 11. Modern view of the hydraulic turbine hall of the Dneprovskaya HPP with installed power of $1548 \mathrm{MW}$ [15] 
Fig. 12 shows the general view of the reinforced concrete dam and the machine of the legendary Dneprovskaya HPP which has repeatedly «experienced» in the 20th century joyful and tragic events in its history [4].

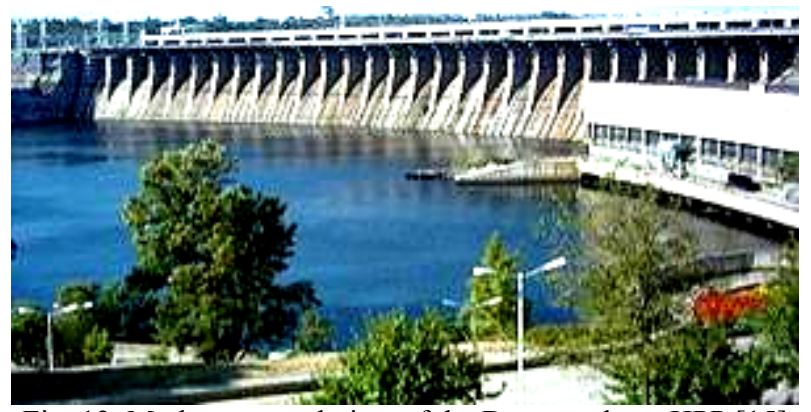

Fig. 12. Modern general view of the Dneprovskaya HPP [15]

At present, in the annual balance sheet of power generation in Ukraine, HPPs occupy the third place after nuclear and thermal power plants. The installed power (about 4.7 GW) of all HPPs in the country is approximately $8 \%$ of the total power of the United Energy System of Ukraine [16, 17]. The average annual output of electricity by domestic HPPs is approximately 10.8 billion $\mathrm{kWh}$ [18]. The main hydropower potential in the country is concentrated on the base of the Dneprovsky hydro-cascade, including [17]: Dneprovskaya HPP (power is $1548 \mathrm{MW}$ ); Kremenchug HPP (power is $682 \mathrm{MW}$ ); Kanevskaya HPP (power is $444 \mathrm{MW}$ ); Kiev HPP (power is $408 \mathrm{MW}$ ); Kakhovskaya HPP (power is $351 \mathrm{MW}$ ); Srednedniprovskaya HPP (power is $352 \mathrm{MW}$ ). To this should be added Dnestrovskaya-1 HPP (power is $702 \mathrm{MW}$ ) as well as a number of pumped storage power plants in Ukraine [16, 17]: Dnestrovskaya (power is $2268 \mathrm{MW}$ ); Tashlytsky (power is $302 \mathrm{MW}$ ); Kiev (power is $235 \mathrm{MW}$ ) should be added. In addition, in Ukraine, 49 so-called small hydraulic power stations operate in rural areas generating up to 200 million $\mathrm{kWh}$ of electricity per year $[6,17]$. Note that the cost of electricity from HPPs is much lower than from the thermal power plants of Ukraine $[2,4]$.

5. Advantages and disadvantages of HPPs. The main advantages of HPPs in comparison with other types of power plants are the following [2, 4]:

- the lack of a fuel component in the generation of electricity at HPPs helps to reduce the dependence of the cost of electricity on changes in the world cost of organic fuels;

- use of renewable energy sources at HPPs to produce electricity which contributes to the global efforts of mankind in the fight to reduce emissions of terrestrial greenhouse gases and harmful chemical compounds;

- HPPs are a key element in ensuring the system reliability of the operation of a united electric power system of any country;

- the value of the electricity generated by world's hydroelectric power plants is lower (approximately up to two times) than in other types by traditional power plants;

- the service life of the HPP facilities and power units is higher than at thermal and nuclear power plants (the main reason for this is the absence of high-intensity thermal processes during the generation of electricity in HPPs, the minimum service life of powerful HPPs is 50 years);

- flexibility of HPP operation, associated with a very rapid decrease in the generation of electricity on it, if there is an excess of the latter in the power system (the power units of the HPP can change their operating mode from «cold» start to full electric load acceptance for up to 1.5 minutes);

- low operating costs associated with the presence of a relatively small number of personnel serving the power units at the HPP.

The main shortcomings of the powerful HPPs of the above-mentioned type include the following $[2,19,20]$ :

- due to the creation of huge reservoirs in HPPs, it is necessary to flood large areas with fertile lands which causes a number of negative changes in the surrounding nature (the withdrawal of large areas of land from agricultural rotation, the presence of stagnant phenomena in water reservoirs deteriorating the quality of river drinking water, dams of plants overlap the fish path to spawning grounds);

- the cost of building a HPP (at an average world cost of electricity produced up to 5 US cents per $\mathrm{kWh}$ ) is higher than for thermal and nuclear power plants of the same electrical power;

- major accidents on the dams of powerful hydroelectric power plants inevitably lead to catastrophic floods downstream with severe consequences;

- siltation of the bottom of the HPP reservoirs which inevitably leads to an increase in the external horizontal pressure on the reinforced concrete dam and to the additional formation of methane and greenhouse gases entering the Earth's atmosphere in reservoirs;

- the need to relocate a large number of people living in the future reservoirs of the hydroelectric power station (according to the World Commission on Dams in 2000, the beginning of the construction of the HPP led to the resettlement of up to 60 million people worldwide).

6. Volumes of hydropower generation in the industrialized countries of the world. As of 2012 , hydropower engineering provided electricity up to $21 \%$ of the total annual electricity production in the world $[4,11]$. At that time, the installed power of the world's hydroelectric power plants was about $715 \mathrm{GW}$. The world leaders in generating electricity at HPPs in its absolute values are currently the PRC, Canada and Brazil. Leaders for the production of electricity at HPPs per citizen are Norway, Iceland and Canada [4]. At the beginning of the 2000s, China was the world's most active hydroconstruction, for which hydropower is still the main potential source of energy in the country. It should be noted that now the PRC implements the world's largest program of building new powerful nuclear power plants on its territory [12]. Note that in 1990, the former USSR came second in the world (immediately after the USA) at HPP installed power of $65 \mathrm{GW}$ [4]. Then the USSR for the production of electric power at the hydroelectric power plants with its annual volume of 233 billion $\mathrm{kWh}$ occupied the third place in the world after the USA and Canada [11]. At present, Russia, with the installed 
capacity of its hydroelectric generating units of $45 \mathrm{GW}$ (the fifth in the world), produces only about 165 billion $\mathrm{kWh} /$ year (also the fifth largest in the world) at the hydroelectric power station [4]. Fig. 13 is a structural diagram of the distribution of currently installed power among thermal, nuclear and hydropower plants in Russia $[4,11]$.

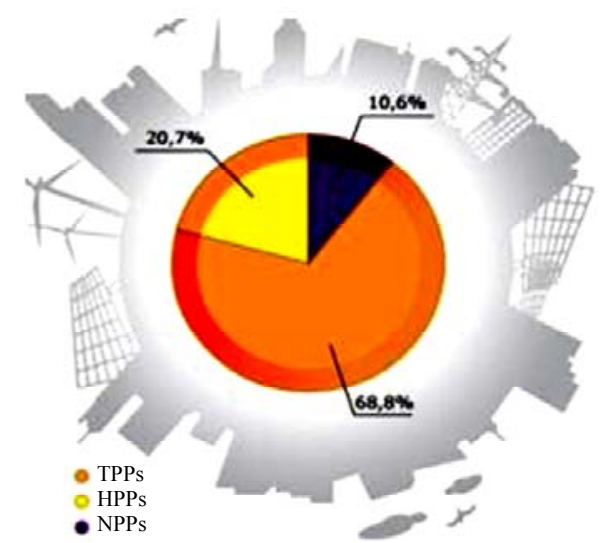

Fig. 13. Structure of distribution of installed power of power plants in the Unified Energy System of Russia for traditional types of electricity generation [4]

From the data in Fig. 13 it can be seen that the share of electricity generated by Russia's hydropower plants in the total volume of its annual production does not exceed $21 \%$. The bulk of electricity in Russia (about $69 \%$ ) is currently being produced at its thermal power plants $[4,8]$. Russia's powerful nuclear power plants account for slightly more than $10 \%$ of the total annual electricity production. We point out that Russia's hydropower engineering, according to its energy-economic potential, amounting to about 852 billion $\mathrm{kWh} /$ year, ranks the second in the world after the PRC [4]. However, in terms of development of its huge hydropower resources, Russia is inferior to virtually all industrialized countries of our world.

7. The problematic tasks of hydropower engineering. The global problem of our civilization is the preservation of a state of the environment that is safe for humanity. In this regard, one of the problematic tasks of the world hydropower engineering, using renewable and environmentally friendly hydropower resources, is to increase the reliability and safety level of hydraulic structures of powerful hydroelectric power plants. These measures should exclude major accidents on the dams of powerful HPPs. Another of its problematic tasks is to minimize the negative environmental consequences from the construction and operation of powerful HPPs. To solve this, large financial investments are required in protective measures to minimize the negative impact of powerful HPPs on the environment. Here, emphasis should be placed on maintaining high quality of water in reservoirs and ensuring the passage in the spring period of fish to their spawning grounds. Hydropower engineering is a relatively highly manoeuvrable energy sub-sector. Therefore, the third problematic task in the field of hydropower engineering is to increase the power of its pumped storage stations in the total power of the power system, including in the United Energy System of Ukraine. In the opinion of hydropower specialists, pumped storage stations should have aggregate power of up to $10-12 \%$ of the total power of all power plants in the country [21]. In this case, when such HPPs are connected to the united power system, optimal passage and regulation of peak electrical loads in the evening time is provided, and a necessary load reserve of the power system is created in emergency situations.

8. Prospects for the development of HPPs in the world and Ukraine. Experts' forecasts point to a steady increase in the world's consumption of electricity and water resources. Thus, according to the available forecasts, the world consumption of electricity in the period from 2000 to 2300 will double in size [21]. In this regard, the role of hydropower engineering in the countries where there are undeveloped hydropower resources is also increasing. It should be noted that as of 2007, in which the world's HPPs generated in the amount of about 3,050 billion $\mathrm{kWh}$, the untapped hydropower potential in the world was about 5,680 billion $\mathrm{kWh}$ [21]. Between the continents of our planet, this energy potential was distributed as follows [21]: Asia - 3380 billion $\mathrm{kWh}$ (60\%); South America - 930 billion kWh (16\%); Africa - 750 billion kWh (13\%); North and Central Americas 350 billion $\mathrm{kWh}$ (6\%); Europe -220 billion $\mathrm{kWh}(4 \%)$; Australia and Oceania - 50 billion kWh (1 \%). In Ukraine, the hydropower potential of flat rivers has been used almost completely [18]. Therefore, for Ukraine, the development of the hydraulic storage of energy, whose energy potential can fully ensure the country's energy system in the deficit of «peak» electricity, is now topical. According to [21], the undeveloped hydropower potential is located mainly in the underdeveloped and developing countries of the world. When planning the development of energy in these countries, first of all, it is planned to develop its hydro resources. The forecasts for the development of the world power engineering up to 2030 indicate that the share of hydropower (up to $21 \%$ ) in the world energy balance will remain so far [21].

\section{Conclusions.}

1. The completed scientific and technical review of the development of the world hydropower engineering indicates that HPPs in the industrialized countries occupy the third place in terms of the annual volume of electricity they produce (up to $21 \%$ of the world's generation) in the industrialized countries after powerful thermal and nuclear power plants. The main reserve of hydropower resources, which has not been currently available in the world (up to 3380 billion $\mathrm{kWh}$ ), is concentrated in the countries of Asia.

2. Hydropower engineering with its relatively manoeuvrable power units using only renewable and environmentally friendly water energy resources is capable, through the construction of powerful pumped storage power plants, to unload the peak loads of consumers in power systems in the evening and create load reserves to increase the stability of the functioning of power systems in emergency operation modes.

3. In order to protect and preserve the environment on the Earth, it is necessary to improve the environmental safety of the existing and newly created powerful conventional HPPs and pumped storage plants in the world. 
4. In the near future, hydropower engineering will continue, together with heat and nuclear power engineering, to remain the main sources of electricity for the developing civilization on our planet.

\section{REFERENCES}

1. Kuz'michev V.E. Zakony i formuly fiziki [Laws and formulas of physics]. Kiev, Naukova Dumka Publ., 1989. 864 p. (Rus).

2. Available

https://ru.wikipedia.org/wiki/Гидроэлектростанция (accessed 13 May 2017). (Rus).

3. Baranov M.I. An anthology of the distinguished achievements in science and technique. Part 40: The scientific opening of the method of explosive implosion for the obtaining above critical mass of nuclear charge and Ukrainian «track» in the «Manhattan» American atomic project. Electrical engineering \& electromechanics, 2017, no.5, pp. 3-13. doi: 10.20998/2074-272X.2017.5.01.

4. Available

http://greenevolution.ru/enc/wiki/gidroelektrostanciya-ges (accessed 22 June 2016).

5. Bol'shoj illjustrirovannyj slovar' inostrannyh slov [Large illustrated dictionary of foreign words]. Moscow, Russkie slovari Publ., 2004. 957 p. (Rus).

6. Baranov M.I. An anthology of the distinguished achievements in science and technique. Part 32: Alternative energy: state and prospects of development. Electrical engineering \& electromechanics, 2016, no.3, pp. 3-16. doi: 10.20998/2074-272X.2016.3.01.

7. Available at: http://www.cshp.ru/gidroenergetika/etointeresno/tipyi-gidroturbin (accessed 05 May 2017).

8. Baranov M.I. An anthology of the distinguished achievements in science and technique. Part 43: Traditional power engineering. Thermal power plants: state and prospects of their development. Electrical engineering \& electromechanics, 2018, no.2, pp. 3-10. doi: 10.20998/2074-272X.2018.2.01.

9. Available at: http://blog.rushydro.ru/?p=4158 (accessed 15 April 2016). (Rus).

10. Available

http://elektrogenerator.net/smallhydropower/pelton turbines.ht ml (accessed 05 September 2016). (Rus).

11. Available at: http://bibliofond.ru/view.aspx?id=657541 (accessed 26 October 2016). (Rus).

How to cite this article:

Baranov M.I. An anthology of the distinguished achievements in science and technique. Part 45: Traditional power engineering. Hydraulic power plants: state and prospects of their development. Electrical engineering \& electromechanics, 2018, no.4, pp. 3-10. doi: 10.20998/2074-272X.2018.4.01.
12. Baranov M.I. An anthology of the distinguished achievements in science and technique. Part 44: Traditional power engineering. Nuclear power stations: retrospective view, state and prospects of their development. Electrical engineering \& electromechanics, 2018, no.3, pp. 3-16. doi: 10.20998/2074272X.2018.3.01.

13. Available at: http://electricalschool.info/energy/1911princip-raboty-gidrojelektrostancii.html (accessed 05 May 2014). (Rus).

14. Available at: http://frend.org.ua/post138322582 (accessed 22 July 2016). (Rus).

15. Available at: https://en.wikipedia.org/wiki/Dnieper_Hydroelectric_Station (accessed 12 May 2017).

16. Available

at: https://ru.wikipedia.org/wiki/Список_гидроэлектростанций_y краины (accessed 02 February 2017). (Rus).

17. Available

at:

https://uk.wikipedia.org/wiki/Гідроенергетика України (accessed 12 June 2017). (Ukr).

18. Available

at: http://mpe.kmu.gov.ua/minugol/control/uk/publish/article?art id =93710\&cat id=35082 (accessed 10 May 2015). (Ukr).

19. Available at: http://myelectro.com.ua/98gidroenergetika/111-glavnye-dostoinstva-i-nedostatki-

gidroelektrostantsij (accessed 10 October 2015). (Rus).

20. Neporozhniy P.S., Obrezkov V.I. Vvedenie v spedsial'nost': gidroelekroenergetika [Introduction to the specialty: Hydropower]. Moscow, Energoizdat Publ., 1982. 304 p. (Rus).

21. Available at: http://energetika.in.ua/ua/books/book-3/part2/section-6/Розділ 6 (accessed 15 September 2016). (Rus).

Received 28.08.2017

M.I. Baranov, Doctor of Technical Science, Chief Researcher, Scientific-\&-Research Planning-\&-Design Institute «Molniya» National Technical University «Kharkiv Polytechnic Institute», 47, Shevchenko Str., Kharkiv, 61013, Ukraine, phone +380 577076841 , e-mail: baranovmi@kpi.kharkov.ua 